\title{
Unleashing Public Private Partnership Understanding and the Ideal Underpinning Theories: A Public Sector View
}

\author{
Jude Thaddeo Mugarura ${ }^{1}$, Zwelinzima Ndevu ${ }^{2}$ \& Peter Turyakira ${ }^{1}$ \\ ${ }^{1}$ Makerere University, Uganda \\ ${ }^{2}$ Stellenbosch University, South Africa \\ Correspondence: Jude Thaddeo Mugarura, Makerere University, Uganda. E-mail: mugarurajude@yahoo.com
}

\author{
Received: August 16, 2019 Accepted: March 1, 2020 Online Published: April 29, 2020 \\ doi:10.5539/par.v9n1p14 URL: http://dx.doi.org/10.5539/par.v9n1p14
}

\begin{abstract}
Researchers ceaselessly theorize public private partnerships (PPP) as a major innovative means to unlock public sector investment gaps, yet their contribution towards improved public service delivery has sustainably remained low mainly due to poor PPP understanding and application. This study utilises extant conceptual and theoretical studies through content analysis to provide a more concrete understanding of the PPP concept and philosophy for their effective application. The study developed a list of common PPP defining features (e.g. partnership, long-term projects and contracts, incomplete contracts, function specific tasks) and eight PPP perspectives (i.e. procurement management, urban regeneration, infrastructure, policy, moral regeneration, financing arrangements, language game, development) for better understanding of the PPP concept. Importantly, the study introduces a new and overarching PPP perspective of procurement management. Additionally, it was established that Traditional Public Management theory is not compatible with PPP practices, and the study recommends new public governance, public value, new public service, and remotely, the new public management as the most appropriate theories underpinning PPPs with in a public sector setting. This research contributes towards improved understandability of the PPP phenomenon and its practical applicability for greater impact towards sustainable public service delivery.
\end{abstract}

Keywords: public private partnership, theories, definitions, perspectives, understanding

\section{Introduction}

With majority of the countries across the globe having for decades faced budgetary constraints and pressure from the citizens to expand and improve public facilities and services (Shetterly, Duan, Krishnamoorthy, Kronenburg \& Loutzenhiser, 2012), governments' public infrastructure development monopoly is soon becoming history. According to Airoldi, Chua, Gerbert, Justus and Rilo (2013), globally there is a \$1-1.5 trillion annual gap against the necessary $\$ 4$ trillion annual infrastructure investment up to 2030. This necessitates governments to collaborate with the private sector to bridge the financial and management gaps. Among the models of private organisations engagement, for instance, contracting-out, privatization and public private partnership, the latter has been highly recommended for public infrastructure development (Hodge, Greve \& Biygautane, 2018; Martin, Lawther, Hodge \& Greve, 2013).

Starting from the early 1990s to-date, public private partnerships have relentlessly gained public sector popularity across the globe because of the consistent government financial constraints, and administration reforms such as governments playing "an enabling" rather than "an active" role in the provision of public services (Reim, 2009, p.2). This form of public service delivery transforms government departments from being owners and operators of public facilities to becoming procurers of the private sector services through long-term contracts that clearly stipulate the responsibilities of each party (Kalpana, 2014a; Willems, Van Dooren \& Van den Hurk, 2017). Public private partnerships therefore introduce innovative sources of funding and better competencies for public facilities and services management.

While the contribution of PPPs towards effective delivery of public services cannot be ignored, their impact remains negligible because literature seems to have failed to recognise that jumbled PPP understanding and lack of a strong public sector theoretical guidance for PPP governance pose a major challenge to their eventual performance. Yet most if not all PPP performance setbacks, either directly or indirectly emanate from both 
conceptual and philosophical misunderstanding. Against such backdrop, this paper aims to provide concrete meaning to what PPPs are in order to avoid their misconstruction and misapplication in research and policy arenas, and to propose from a public sector perspective the most suitable theories for effective implementation of PPPs.

\section{The Conceptual View of Public Private Partnerships}

Despite enormous literature available about PPPs, there is still a lot of ambiguity on what PPPs really are. As such, a two-strand interrogation of 'PPP definitions' and 'PPP perspectives' is being undertaken to provide more effective meaning and appreciation of the public private partnership phenomenon. A perspective, in this study, does not relate to a particular "methodology, ontology and epistemology", rather to the "general patterns and tendencies in literature" (Weihe, 2008, p.430).

\subsection{Understanding of Public Private Partnerships from Definitions Found in Extant Studies}

Farquharson et al. (2011, p.11) define public private partnerships as "a long-term contract, to which private sector party often agrees with a public entity to design and build, expand, or upgrade the public sector facilities; take up significant monetary, technical, and operational risks; receive a monetary benefit during the life of the contract from users or the public sector, or from a combination of the two; and usually return the facility to public ownership at contract closure". This definition signifies that:

$>\quad$ Project tasks must be bundled into a single or bigger contracts in order for the private partner to bear substantial project risks and management responsibilities;

$>$ Projects together with their contracts must have a long life span;

$>$ Payment to the private partner must come from direct users of the facilities or where deemed necessary by the government itself; and

$>\quad$ Project contracts need to explicitly state how the transfer of infrastructure ownership and responsibilities should be handled at the end of the contract.

To Koppenjan (2005, p.137), PPPs are formal collaborative arrangements between public and private parties in order to effectively plan, construct and/or operate public facilities through sharing or reallocating risks, costs, benefits, resources and responsibilities in a specific project. However, Koppenjan's definition is criticised for being function-specific and disregarding informal and long-term relationships, and failing to draw a line between organisational and inter-organisational objectives, values and visions within PPP policy networks (Hodge \& Greve, 2007; Brinkerhoff \& Brinkerhoff, 2011). Koppenjan's definition was later strengthened by Zhang, Gao, Feng and Sun (2015, p.499) who viewed PPPs as long-term contracts for the support and organization of all stakeholder interests and project processes throughout the lifespan of a developmental project. This implies effective collaborations cannot take place in short-term contracts, and PPP interventions would flourish in environment with synchronized operations and well governed organizational structures.

According to Alinaitwe and Ayesiga (2013), cooperation, as suggested by Zhang et al. (2015) must be based on what each party to the consortium is good at, in the quest to deliver the best services to the public. With a similar perspective, Roberts and Siemiatycki (2015) and Kalpana (2014a) argue that, the essence of any partnership oratory is to gain a networking advantage, where individuals from numerous organisations and disciplines work together to achieve results that cannot be realised in the absence of combined efforts. Consequently, effective PPPs enable accessibility to key resources that may be practically unavailable or inadequate to certain partners to deliver a public service mandate (Brinkerhoff \& Brinkerhoff, 2011). However, critics of PPPs argue that, though governments recognise the need for mutual commitment and cooperation in their PPP policy documents, in practice, PPPs are always transformed into 'contracting out schemes' since private partners are rarely allowed to innovate beyond the explicit contract provisions (Roberts \& Siemiatycki, 2015). More so, the interdependence between partners outside the formal contract is minimal (Hodge \& Greve, 2010). This results into loss of flexibility, yet PPP partners are expected to respect and adapt to changes in the operational environment in order to mitigate against negative significant impacts on the way public services have to be provided overtime (Boardman, Greve, \& Hodge, 2015).

On the basis of their long-term nature and future uncertainty, PPP contracts remain incomplete, hence requiring effective partnership behaviour among all the partners to facilitate continued commitment. This is in agreement with Hodge and Greve (2007) argument that, not everything can be written into a detailed contract under long-term transaction commitments. As such, PPPs working arrangements should be based on shared assurances beyond what is expressed in a contract document (Bovaird, 2004). Upholding such partnership behaviour enables provision of public services based on approaches of mutuality, teamwork, faster dispute resolution, 
continuous improvement, and equitable sharing of profits and losses. Drawing from the discussions so far, we concur with Zhang et al. (2015) postulation that integrating contractual, partnership and function specific views is an effective way of defining the PPP concept. The contractual view emphases the formalities and legalities that bind the public and private sector entities together. The partnership view exhibits the social aspects of mutuality, commitment and trust. The function-specific view is activity-based and uses the project lifecycle approach in executing and shifting (fully or partially) some of the project activities to do with financing, designing, constructing, maintenance and operation from the public to private partners.

In summary, the common elements that define PPPs are public and private sector (inter-organisational) interactions, risk and responsibility sharing or shifting, competitive dialogue, bundling of construction and operation, partnership based long-term contracts in a project setting, output and outcome based specifications that encourage innovation, institutional systems and organisational processes, service delivery objectives/purpose, payment mechanism (through users and government), and developing public facilities or providing public services through private sector financing. While the suggested common elements for defining PPP may not wholly apply to each type of PPP, they provide a benchmarking standard upon which the assigning of wrong meaning to PPPs in both research and policy undertakings can be avoided.

\subsection{Understanding of Public Private Partnerships from Perspectives/Classification in Extant Studies}

According to Wettenhall (2003, p.98), the narrow and unclear coverage of PPP understanding demands conducting further investigations. As such, eight PPP perspectives are being discussed to have the right conceptualisation of PPP arrangements for the future researchers, policy makers and practitioners to use and apply PPPs effectively.

\subsubsection{The Urban Regeneration Perspective}

The urban regeneration perspective focuses on urban economic and social revitalization through cooperation between private businesses and local governments (Weihe, 2008). Partnerships of this nature begin with business transactions between companies or business leaders and are later extended to include the public and third sector actors, who collaboratively work together to respond to urban crises such as increasing unemployment and crime, and poor sanitation and deteriorating revenues (Weihe, 2008). However, sharing of the roles among the partners may vary on case-by-case basis. The features of "co-production, risk-sharing and principal-principal relationships" (Weihe, 2008) mainly define this type of partnership. Interactions among partners may result from mutual interests rather than force, since each participant is viewed as a principal, suggesting an arrangement of equals. This is very different from the dominant Principal-Agent partnership behaviour, where parties often act opportunistically. However, this perspective has two major weaknesses. Firstly, literature remains silent on how cooperation in a principal-principal relationship is executed, whether it is through contractual or non-contractual arrangements or both. Secondly, it over assumes that PPPs only work for urban areas, yet they equally apply to all geographical public service delivery points.

\subsubsection{The Policy Perspective}

Unlike the Urban regeneration perspective that focusses on specific collaborative projects, the policy perspective focusses on describing and analysing the institutional set up of public private cooperation in various policy fields (Weihe, 2008). According to Brinkerhoff and Brinkerhoff (2011), PPPs have become governance tools that seek to plan and implement public policies at different levels of service delivery impacts. However, PPP policies are often undermined by selfish interests of politicians, lobbing groups and bureaucrats, especially in developing countries. Yet, according to Brinkerhoff and Brinkerhoff (2011), an effective PPP policy is one that is specific on; the expertise and experience of partners; the harmonisation of government and community needs; the ability to address the pressing concerns of society; building stakeholder consensus, nurturing sound relationships across institutions; and the lawfulness and credibility of policy players.

In a nutshell, the PPP policy perspective focusses on policy design, policy networks and the appropriate roles of public and private sector players in different policy settings. The approach seems to be more inclined towards PPP policies that have state, national, central and local government impacts.

\subsubsection{The Infrastructure Perspective}

Infrastructure perspective is associated with PPP arrangements, where the private parties participate in the provision of public infrastructure and the delivery of public infrastructure-based services (Weihe, 2008). Infrastructure PPPs foster joint collaborations between the public and private organisations in designing, developing, financing, maintaining and operating of public infrastructure (Brinkerhoff \& Brinkerhoff, 2011; Bayliss \& Van Waeyenberge, 2018) to improve the provision of public services. 
This perspective employs deregulation principles to fix the physical infrastructure investment gaps for sustainable public service provisioning (Ghobadian, Gallear, O’Reagan, \& Viney, 2004, p.6). Though for long, infrastructure PPPs were being applied to only economic infrastructure (motorways, Bridges, tunnels), they have now been extended to social infrastructure such as schools, hospitals, prisons and waste management (Grimsey \& Lewis, 2004). However, this PPP perspective has been criticised for limiting government flexibility, and increasing inefficiency and investment spending. For instance, Brinkerhoff and Brinkerhoff (2011) argue that financing of public infrastructure through user fees denies the poor and marginalised groups the right to access public services.

\subsubsection{The Development Perspective}

Proponents of this perspective view PPPs as a means of reducing poverty, social deprivation, corruption and environmental degradation to enable nations to achieve global development goals at sectoral, community, local and central government levels (Weihe, 2008). For instance, The Global Fund (a partnership initiative between governments, civil society, the private sector and communities) raises and invests nearly US\$4 billion per annum to support programs aimed at fighting diseases such as AIDS, Tuberculosis and Malaria in affected poor countries (The Global Fund, 2016). From the United Nations Sustainable development goal 17 'partnership for goals', it is very clear that the world can achieve its development agenda mainly through partnerships and cooperation. In Canada, for instance, between 2003 and 2012, the delivery of public infrastructure through PPPs approximately improved national income and Gross Domestic Product by $\$ 32.2$ billion and $\$ 48.2$ billion respectively, and added about 517, 000 permanent jobs to the employment grid (Casady, 2016). As such, PPPs support the broader societal objective of socio-economic development (Hodge, 2009). This perspective is mainly promoted by the third sector actors, especially intergovernmental organisations for the development of poor countries.

\subsubsection{The Language Game Perspective}

According to Hodge and Greve (2007) and Linder (1999), the PPP phenomenon has become a language game with multiple grammars attached to its meaning. Scholars that share similar sentiments with Hodge and Greve, and Linder, describe PPPs as a mere fashionable and more appealing terminology than privatization (Greve, 2003, p.60; Hodge, 2004; Kalpana, 2014a, p.10; kalpana, 2014b. p.12). In essence, promoters of the language game perspective suggest that governments name public projects PPPs when in reality they are implementing contracting-out or privatization contracts (Hodge \& Greve, 2005a; Kalpana, 2014a). This often happens with governments that become unpopular because of having grossly mismanagement contracting out or privatization of public facilities. In addition, the PPP language game has led governments in different countries to visualize PPPs in a conflicting and misleading manner. For example, "in Australia, PPPs and privatization are completely different policies, while in the UK, the HM treasury 2003 equates PPPs to privatisation" (Hodge \& Greve, 2010). This example indicates how PPP policies can be classified to fit political selfish interests than advance the right meaning and appreciation of the PPP agenda to the citizens. No wonder PPPs have nowadays become the most developmental talk for government programs and contracts (Hodge \& Greve, 2009).

It can be inferred that, though the Language game debate is critical in framing our understanding of PPPs, researchers and governments should be cautious with how they approach PPPs. It is obvious that PPP advocates will promote the policy positives while omitting the policy negatives, and the reverse is true for PPP adversaries. For instance, Hodge (2004, p.39) asserts that PPP supporters assume PPPs are 'a marriage made in heaven'. This is in agreement with Kalpana (2014b. p. 13) who argues that PPPs provide 'public sector services efficiently and inexpensively, reduce pressure on government budgets, strengthen monitoring and accountability, and evoke business and investor confidence'. Finally, in all honest, it can be categorically stated that, while Sarmento and Renneboog (2016, p.97\&99) crown privatisation a 'public procurement modality as well as insinuations of 'public private partnerships for infrastructure privatization' by $\mathrm{Li}(2017, \mathrm{p} .3)$, rather than being a public service delivery modality, in no way and by no means can privatization be a procurement modality.

\subsubsection{The Procurement Management Perspective}

While literature has paid little attention to this perspective, going by practice PPPs are real procurement management modalities. Scholars that have attempted to view PPP as a procurement only stop at either capturing the 'word' procurement in the term PPP (e.g. 'PPP procurement' or 'PPP procurement option/alternative/modality') or defining it as a procurement phenomenon. Examples of such scholars include; Farquharson et al. (2011); Alinaitwe and Ayesiga (2013); Allen consulting group (2007); Willems and Van Dooren (2016); Sarmento and Renneboog (2016); and Martin et al. (2013). This study therefore seeks to go further than a mere 'definition' or just 'wording' to advance through justification 'PPPs as a procurement 
management perspective', and as 'one of the most critical approaches' of PPP arrangements.

Since the 1980s, for a time now governments have been transforming the provision of public services through procurement devolutions. First was the direct government provisioning mode succeeded by outsourcing, and more recently public private partnerships. None of the three aforementioned procurement modes replaces the other, though direct government provisioning seems to be slowly phasing out in preference for public procurement. While public private partnerships have taken shape, their usage remain low compared to public procurement because of the stringent and fundamental conditions that compel their use. Notwithstanding the dominance of public procurement, according to Reim (2009), PPPs remain a superior procurement mechanism to public procurement and direct government provisioning. This resonates with Weihe (2008) assertion that, public procurement is less appropriate for developing complex and large public infrastructure facilities. Similarly, public private partnerships are principally less appealing to small and low investment procurements. Concisely, small and low investment project are more suitable for public procurement as big and heavy investment projects would be for public private partnerships.

In view of the above, PPPs are renewed and innovative way of purchasing public goods/services, that replaces or complements outsourcing or privatization (Weihe, 2008; Hodge \& Greve, 2007) to solve service delivery challenges beyond the full capacity of government. Uniquely, PPPs 'alter business-government relations from the ethos of command and control regulation to trust and cooperation, from solving differences through litigation to negotiations, and from being adversaries to collaborators' (Linder, 1999, p.47) since each party is expected to extend unalike value to the partnership. Such interactions promote sharing of knowledge, skills, responsibilities and risks in a mutually acceptable and beneficial manner, unlike other procurement modalities. Subsequently, this instills confidence in the private sector and propels public officers beyond the confines of outsourcing to promote private business growth.

From a public sector perspective, the ultimate goal for any PPP project concept is to procure a private sector contractor. The rest of the other project aspirations only come-in to complement or are part of the procured contracts. Therefore, without procuring a private partner (contract), no PPP project exists, and as well, no financing, designing, maintenance and operation tasks would be executed. In fact, according to Sarmento and Renneboog (2016, p.97), the various PPP forms; that is, Build Transfer Operate (BTO), Design Build Finance Operate (DBFO) and Design Own Operate (BOO) are 'different procurement systems'. To make procurement realizable, public officers must develop commercially attractive projects to have private for profit companies invest their capital and expertise in public facilities. Finally, the main benefits of the PPP procurement mechanism to government include; minimized government financing and tax burdens, kickbacks and patronage; and public officers become more entrepreneurial, flexible and innovative in addressing public service delivery challenges (Linder, 1999). For the Private sector, instead of companies competing against one another, they would rather jointly work together (e.g. under the special purpose vehicle (SPV) arrangement) for enhanced benefits.

\subsubsection{The Moral Regeneration Perspective}

Government provisioning is known for harshly treating both the providers and recipients of public services, since it conveys individual and community entitlements and privileges or sanctions and punishments based on either monetary or political support rather than eligibility (Linder, 1999). Accordingly, the desired transformation for improved services would be realized through well-structured public private partnership energies. As a result, development of public infrastructure or service provision need to be moved towards market oriented selfless behavior, creative problem solving and participation in property holding and commercial enterprise. Furthermore, PPPs can relieve government some of the project administrative responsibilities by moving public sector workforce to a more disciplined private sector labour market. Therefore, PPPs come in to deregulate employment disparities for unorganized work force (Supiot, 1996). Linder (1999, p.45) argues that the commercialization of public services is less affected by moral degeneration. Hence, allowing public servants to act like private sector managers has a valuable ethical effect. In conclusion, though government provisioning promotes virtues as well, PPPs arrangements are the ones that foster virtues of the markets that are critical in addressing public service delivery governance problems.

\subsubsection{The Financial Arrangements Perspective}

Many definitions for PPPs indicate financing as one of the key components that motivates governments to partner with private organisations in order to provide better public services (Bayliss \& Van Waeyenberge, 2018). For example, Campbell (2001, as cited in Khanom, 2009) partly defines PPPs as projects for financing public infrastructure. Khanom (2009) suggest that PPP procurement systems (e.g. Build Operate Transfer-BOT, BOO, 
and DBFO, etc.) each presents a unique financing option for projects. For example, with the DBFO PPP model, the private sector takes up all the financing responsibilities for the planning, building, maintaining and operating facilities until the expiry of the project contract time. In return, the private investors benefit from the operation of the developed infrastructure through government payments or direct user charges, such as road tolls. However, to make private sector financing initiatives realisable, public sector entities must structure projects that are attractive for private sector investment. In reality, PPP arrangements have become interventions for reducing pressure on government budget to deliver public infrastructure sooner than later (Linder, 1999; Khanom, 2009). To conclude, PPPs are a financing tool to the private sector through revenue collection during operation stage, and to the public sector by leveraging private funding for public infrastructure development and service provision. As such, the private sector uses PPPs for profit making, while the public sector's main interest is in improving service delivery.

In summary, the eight PPP perspectives advanced cover a wide range of governance issues with different focus group territories, characteristics, mechanisms, and each with shared or different accountability implications. The aforementioned PPP perspectives enable researchers and policy makers appreciate the different formal/contract structures, actors, objectives, significance, contexts and culture that shape the PPP understanding, and their unique, complementary and at times overlapping governance roles in public service delivery. Most importantly, the study introduces a new PPP perspective of procurement management to literature.

\section{The Theoretical View of Public Private Partnerships}

Several theories such as the game, principal-agent, incentive, institutional, stakeholder, networking, property rights, market failure and transaction cost economics have been used to explain public private partnerships. Such aforementioned theories and many others carry a more general view of PPPs; as such, they lack the rigour or the required emphasis of public sector perspective of service delivery. Therefore, this paper adopts five theories; the traditional public administration (TPA), the new public management (NPM), the new public service (NPS), the public value (PV) and the new public governance (NPG) theories as the most suitable paradigms for public service management. We intend to discuss each of the five selected theories of public governance, and thereafter propose with justification the most appropriate/relevant theories that underpin public private partnership phenomenon for effective public service delivery. Nevertheless, the more generic theories already highlighted, where found relevant, their philosophical foundations are used to provide balanced phenomenological arguments in the study.

\subsection{Traditional Public Administration Theory (TPA)}

TPA theory 'the efficacy of the policy formulation process and the extent to which public policy implementation addresses aspirations of the existing public policies' (Osborne, 2010, p.415). According to Xu, Sun and $\mathrm{Si}$ (2015, p.15), in countries with inefficient market mechanisms and immature third sector, the regime in power behaves more of the alpha and the omega in the organisation of political and public service delivery agendas. Ironically, the government would meet all society satisfiers without considering the 'real' needs of the citizens. Such a public system of governance is too radical, in that any problematic trigger from the centre would automatically lead to the malfunctioning of the entire system (Xu et al., 2015). Subsequently, as government failures surpass market failures, open and competitive private sector participation becomes the best option (Byamugisha \& Basheka, 2016). From such deductions, it is eminent that TPA is not suitable for PPPs in both theoretical advancements and practice.

\subsubsection{Demystifying the Inapplicability of TPA Theory to Public Private Partnerships}

With this theory, the government disassociates itself from partnership relationships with the service provider and the receiver. As such, the involvement of private organisations or citizens in the delivery of public services would be transactional in nature and at arm's length level. The existence of cooperation between the government, citizens and the private firms is almost non-existent, in that, away from the time of actual transacting or service provision, there is no relationship to be maintained. Therefore, TPA aims at fostering top-down governance structures, where public service provision is a full responsibility of public managers who seem to only be accountable to their political masters. Under such governance systems, the public managers do not serve the interests of the broader society but aim at pleasing a small group of elected officials who illogically pay allegiance to their political parties' positions or advance personal political agendas at the expense of the citizens' wellbeing. Actually, as Willems and Van Dooren (2016) put it, TPA produces short-sighted and unstable public policies formulated to address the egocentric needs of the most influential and well-organised team (of course in crime), bureaucrats inclusive. 


\subsection{New Public Management Theory}

In response to the inadequacies and bureaucratic nature of TPA emerged the NPM theory, which introduces the methods of business or enterprise management to government (Xu et al., 2015). As Peters (2010, p.40) puts it, the delivery of public service through bureaucratic processes is not only 'clumsy, ineffective but also unresponsive'. However, developing countries have not yet substantially replaced TPA with NPM practices because most government functions continue to be vertically executed (Mongkol, 2011; Xu et al., 2015). NPM reforms broadly aim at improving public services through a dual 'government- market' structure (Mongkol, 2011, p.35) where government contributes capital to outsource public goods and services from the private sector. Summarily, NPM practices pay more devotion to the government-market collaborations (Bonina \& Cordella, 2009; Bao, Wang, Larsen \& Morgan, 2012; Xu et al., 2015), thus, 'privileging the private over the public sector, the individual over the community, the consumer over the citizen, rivalry over cooperation, passive over active engagement, and individual interest over the common good aspirations' (Benington, 2007, p.2-5).

\subsubsection{Demystifying the Relevance of NPM Theory to Public Private Partnerships}

The public sector focuses on formulating policies and controlling the way public services are provided by the private for profit organizations through specific performance indicators, monitoring and market based mechanisms. Public private partnership arrangements are purely constructed along commercial lines with the intentions of achieving value for money by integrating some or all the public infrastructure project tasks into a single long-term contract indorsed through a competitive tendering process. This mainly applies to PPP Operate and Maintain (O\&M) concessions. Because of the open and competitive procurement methods used, PPPs enable facility users (i.e. only direct users) to not only participate in the processes of public policy definition but also influence the type and quality of service delivered. The efficiency of NPM to PPPs is two-fold. First, because of the longevity of the PPP contracts, the private sector is able to make reasonable returns since the initial heavy investment expenses are compensated with the reduced future maintenance and operational costs. Second, the government can afford to transfer majority of the responsibilities and their associated problems to more capable, experienced and skilled private firms whose payment is dependent on making the physical infrastructure available and operating the same facility to provide the desired service. However, where turnkey contracts or special purpose vehicle arrangements are not used, the NPM philosophy becomes more applicable to conventional procurement (public procurement) rather than PPPs.

\subsection{New Public Service Theory}

NPS theory is a movement built on the ideals of equality among the citizens (Denhardt \& Denhardt, 2015), and is a governance scheme that makes citizens the main focus during the management of public affairs (Denhardt \& Denhardt, 2000). Government is expected to actively extent avenues through which the public can engage and discuss issues of common interests (Denhardt \& Denhardt, 2007, p.66) than impose unclear and unpopular developmental schemes (Denhardt \& Denhardt, 2015, p.669). As such, citizens expect public service to meet standards of; convenience, security, reliability, personal attention, problem-solving approach, fairness, value for money, and citizen influence (Denhardt \& Denhardt, 2007).

Mingus and Zhu (2018, p.375) argue that the NPS movement, is part and parcel of the current transformations within the political, social, and enterprise systems. However, it is wrong for bureaucrats to often think that their own view of public needs supersedes the perceptions of the rest of the stakeholders (Denhardt \& Denhardt, 2007, p.80). Instead, public administrators need to avail avenues that would nurture long term collaborations with public service consumers and advocators (Denhardt \& Denhardt, 2015, p.665), while avoiding unsustainable solutions emanating from personal decisions (Denhardt \& Denhardt, 2015, p.668). In the long run, both the citizenry and government officials appreciate the complementary role of each other (Denhardt \& Denhardt, 2007). This in turn, increases citizens' commitment and readiness to pay for use of public investments, and the government getting energised to ensure that citizens receive best public services from private sector investors (Denhardt \& Denhardt, 2015).

\subsubsection{Demystifying the Relevance of NPS Theory to Public Private Partnerships}

New public service focuses public service provision on complying with public interests through collaborative relationships, shared responsibilities and common understanding of public issues, and active involvement of citizens in government activities (Robinson, 2015). New public service practices ensure that PPPs meet the collective public interests, since public servants are given the mandate to develop innovative ways of consolidating civilian participation in providing solutions to community challenges. The bureaucrats are expected to pursue the implementation of PPP policy through brokering, negotiation and resolving complex service delivery problems in partnership with the citizens. Furthermore, the accountability of public servants 
extends beyond elected officials to incorporate other public sector stakeholders (Robinson, 2015). The key role of government is to provide an environment in which PPPs can address society's service delivery needs through dialogue, open, flexible, accountable, accessible, and transparent means and structures.

\subsection{Public Value Theory}

Public value is value realised at the macro, but not at a micro level of public service consumption (Alford \& Hughes, 2008). Spano (2009, p.330) points out that value is created as long as the advantages of an intervention surpass its costs. At a society level, public values provide "normative consensus about (a) the rights, benefits and prerogatives to which citizens should (and should not) be entitled, (b) the obligations of citizens to society, state, and one another, and (c) the principles on which governments and policies should be based' (Bozeman, 2007). Therefore, Public value is a rigorous way of resolving democratic deficits, judging the viability of projects, decision making, and defining, measuring and improving performance (Rutgers, 2015; Sufna \& Fernand, 2015). Resultantly, PV delivers both democratic values (equity, honesty and fairness), and the managerial values (efficiency and effectiveness) in the performance of tasks (Bonina \& Cordella, 2009).

Based on the above deductions, PV practices maximise citizen welfare by remedying market failures of negative externalities, natural monopolies and imperfect information, and increases trust for and legitimacy of the government (Alford \& Hughes, 2008; Talbot, 2008). Such translate into; (a) generation of economic activities and employment, (b) improved social networking for prosperity, (c) transparent discussions and citizen involvement (d) morality regeneration and reduced environmental degradation (Benington, 2007). Notwithstanding the aforementioned benefits, PV is criticised for focusing on achieving and measuring medium to long-term targets, yet governments that are dictated by the voting processes emphasize short term targets. However, this can be contained if the public servants concentrated on program politics than partisan politics (Benington, 2007:17), because the real political environment can limit their autonomy in service delivery (Alford \& Hughes, 2008).

\subsubsection{Demystifying the Relevance of PV Theory to Public Private Partnerships}

Like the New public service theory, public value theory promotes accountability of public organizations not only to their political masters but to the citizens as well. It moves beyond political democracy that limits itself to the ballot box, to a level where bureaucrats have the capacity to satisfy citizens' preferences through administrative systems that are more sensitive to local conditions (Blaug, Horner \& Lekhi, 2006). For PPPs to positively influence service delivery, public institutions need to shape and inform public interests based on purposeful interactions, logical and transformative choices, rather than succumb to the unrealistic dictates of the general public (Blaug et al., 2006). This is possible, only if public managers have the capacity and use innovative means to influence institutions, politicians and citizens to positively respond to the refined public preferences. Basing on Coats (2006) suggestions, public managers can ensure PPPs deliver value to the public through increased, improved, responsive, transparent and innovative citizen oriented approaches.

One of the important tools for advancing public value paradigm in a real PPP environment is the "Public Value Scorecard" developed by Meynhardt (2012). It is an effective management tool for assessing the viability of proposed PPP projects and evaluating the appropriateness of project implementation decisions using the chance and risk approach. The tool assesses and evaluates the various PPP operational structures and system environments while making a tradeoff among five dimensions of profitability, usefulness, decency, positive experience, and political realism/acceptance. As such the Public Value Scorecard ensures that PPP policies and performance targets are legitimate, feasible, sustainable, ethical, and adequate to citizens and the private actors.

In summary, PV approach provides tools to demonstrate why public money should be or how it was spent on PPPs; advances actions that are based on informed solutions; challenges an only technocratic led performance approach; appreciates the input of service users and citizens; sensitizes the citizens about the challenges faced by both politicians and public managers, and the limits of what can possibly be offered; and ensures effective management of political risks (Coyle \& Woolard, 2010).

\subsection{New Public Governance Theory (NPG)}

NPG is a mode of practice that is more adapted to the most recent style of managing public operations (Xu et al., 2015). It agitates for sustainability of public policy, public services, public service organisations, societal and environmental concerns (Osborne, 2010) by creating transparent activities, processes and open structures that are more socially responsive (Patapas \& Smalskys, 2014). It views management of public affairs from several governance strands, which include among others, policy, administration, social, economic, political, contractual, decentre, corporate, meta and networking (Osborne, 2010; Rhodes, 1996; Rhodes, 2016). The theory is centred 
on the effective management of intra and inter-organisational environmental pressures that can permit or curtail policy execution to deliver public services with in a plural and pluralist structure (Osborne, 2010). In fact, with in a well-functioning public sector system, society needs are satisfied through consensus building among the various actors, yet more often with differing interests and values (Koenig-Archibugi, 2003, p.319). This argument is supported by Kooiman (1993, p.4) in the assertion that, no actor would have all the resources, capacity and enough influence to singlehandedly solve society problems.

New public governance practices appreciate the transformation of public service delivery through a multiple of processes and actors based on both formal and informal interactions (Kennett, 2010). This enables the development of more networked and citizen focused service delivery approaches that promote self- sustaining initiatives, close shareholder collaborations and continuous improvement practices for the wellbeing and satisfaction of the community (Benington, 2007).

\subsubsection{Demystifying the Relevance of NPG theory to Public Private Partnerships}

NPG practices focus on how guidelines and standards are increasingly co-formulated and co-regulated by government, citizens and non-government players through autonomy and authority sharing to deliver public services. NPG encourages the provision of public service through PPPs based on joint collaboration and governance led networks to enable actual interaction, horizontal power relations, close organisational relations, trust, reputation, reciprocity, mutual interdependence and joint decision-making (Stelling, 2014; Mauri \& Muccio, 2012). Accordingly, PPPs have become an ongoing reconfiguration of authority in the world of politics (Stelling, 2014). This assertion is justified by the current governance and management systems that promote coexistence of institutional, contractual and informal network structures in which citizens, government, private sector and civil society organizations are given an opportunity to collectively direct and participate in the provision of public services. This prompts PPP operations to be coordinated with in well-networked organizational structures, managerial and institutional strategies that are directed towards the achievement of universally determined service delivery outcomes. In fact, the co-production and co-regulation initiatives advanced by the new public governance approach enable public service stakeholders to exchange information among themselves to have better PPP inventions of solving intricate society problems (Klijn, 2010).

In conclusion, as Villanueva (2015) states, the new pubic governance practices are now being institutionalised by passing of PPP ACTS; and such legislations recognise the insufficiency and lack of self-sufficiency of government, and acknowledges the relevance of adding on private and social resources to existing public ones in order to strengthen the society and government's capacities to tackle critical problems and promote relevant projects.

On the basis of the five theories discussed above, two positions have been taken:

* TPA is not compatible with PPP principles and practices. This is due to the fact that it does not encourage the involvement of private sector through competitive and partnership means, does not allow the public servants and private sector players to innovative, minimizes the influence of the third sector, payments for services are either in advance or shortly after delivery but not on long term accrual basis, and leaves government to be the only developer and implementer of public policies in the delivery of public services.

* NPM, NPS, PV and NPG are the most relevant PPP theories based on a public sector viewpoint. This paper recommends more than one theory (only four) because; in our view though a single overarching theory for PPPs has emerged (i.e. the NPG), public sector practices have not yet fully appreciated it. Actually, public sector operations currently meander in all the five theories (i.e. including TPA) trying to find a better fix of PPP excellence.

\section{Implications to Policy/Research}

The key implications of the discussions on the conceptual and theoretical views of PPPs are presented with the aim of creating clarity of what PPPs are and are not, as well as providing guidance to researchers, policy formulators and implementers on how to effectively plan and execute PPP undertakings.

\subsection{Conceptual Understanding of Public Private Partnerships}

Based on our previous discussions about PPP definitions and perspectives, it is clear that PPPs are in different forms, and have diverse understandings and applications. The insinuations from literature discourse that the PPP confusion can be solved by having a single and over-arching PPP definition or strand, is not only illogical but also irrelevant, given the existence of different PPP research traditions with different knowledge clusters and usage (Weihe, 2008). Relatedly, Boardman et al. (2015) and Hodge et al. (2018) logically argue that there has and will never exist, one universally acceptable PPP modality. They justified their reasoning in the notion that 
there are many PPP delivery options or contract arrangements with seemingly different project planning, risk sharing, building, monitoring, maintaining, financing and operating procedures, objectives, incentives to the beneficiaries; and handling of transparency, accountability and other governance aspects.

In fact, the misunderstanding about what PPPs are and what they are not, is because of the failure to acknowledge the existence and making use of the uniqueness in the different PPP perspectives. The uniqueness found in the different PPP perspectives can be manifested in the statements below;

$>$ The third sector is a common participant in the development PPPs than in other PPP types (Weihe, 2008, p.435).

> Principal-principal relationship applies to urban regeneration approach while infrastructure PPP strand is based on Principal-Agent relationship (Weihe, 2008, p.435).

> Defining PPPs as long-term contract does not apply to all PPPs (Weihe, 2008, p.435). For example, development PPPs can either have short or long-term contracts depending on the magnitude of the intervention being undertaken and the availability of the resources required.

$>$ Co-production and collaboration in infrastructure PPPs are limited, since the private actors sign contracts which obligate them to deliver specific services, with in specific times at fixed prices (weihe, 2008, p.435; Hodge and Greve, 2005b, p.6).

$>$ Contrary to partnership principles, formal contractual relationships expressed in many PPP definitions lower the degree of mutuality (Brinkerhoff \& Brinkerhoff, 2011, p.6).

Boardman et al. (2015) attribute variations in the understanding of PPPs to: the distinctiveness in legal perspectives with differing financial and risk sharing proportions; cross organisational and national operations; the availability of numerous stakeholders with a magnitude of objectives that keep changing; uniqueness in public accounting across environments; and the difficulty in obtaining accurate and relevant data on cross-national policy lessons, institutional arrangements, and on performance standards and outcomes, that gives a chance to lazy PPP researchers to selectively bend PPP evaluations to their own interests of either successes or failures.

Drawing from Khanom (2009), it can be concluded that, inappropriate conceptualisation when defining and designing PPPs can be mitigated through:

$>$ recognising that there are several categories of PPP (e.g. BOT, DBFO, BOO, BOOT) with different governance, management and policy design requirements;

$>\quad$ being precise on the common institutional structures, monetary matters, and partnership behaviour traits;

$>$ being specific on decision-making processes, obligations of the various institutional players different organisations/actors in both policy and contract frameworks;

$>\quad$ being clear on the roles of the different policy communities and policy networks (including third sector);

$>$ being specific on the purpose (e.g. community development, poverty alleviation or infrastructure development);

$>$ setting a specific agenda for all the players to realise a PPP outcome; and

$>$ taking into account the political culture within which PPP projects have to operate.

\subsection{Theoretical Underpinning of Public Private Partnerships}

Drawing from our previous discussions and a "PPP concept" framework developed by Stelling (2014), PPPs lie between either "contracting-out and private provision", or "contracting-out and public provision". Note that, compared to contracting-out, PPPs extend more public service delivery responsibilities to the private firms. In this analysis, public private partnership approaches suggested by Stelling (2014) in figure 1 below, are matched with the four theories found suitable for PPP advancements in the earlier discussion. 


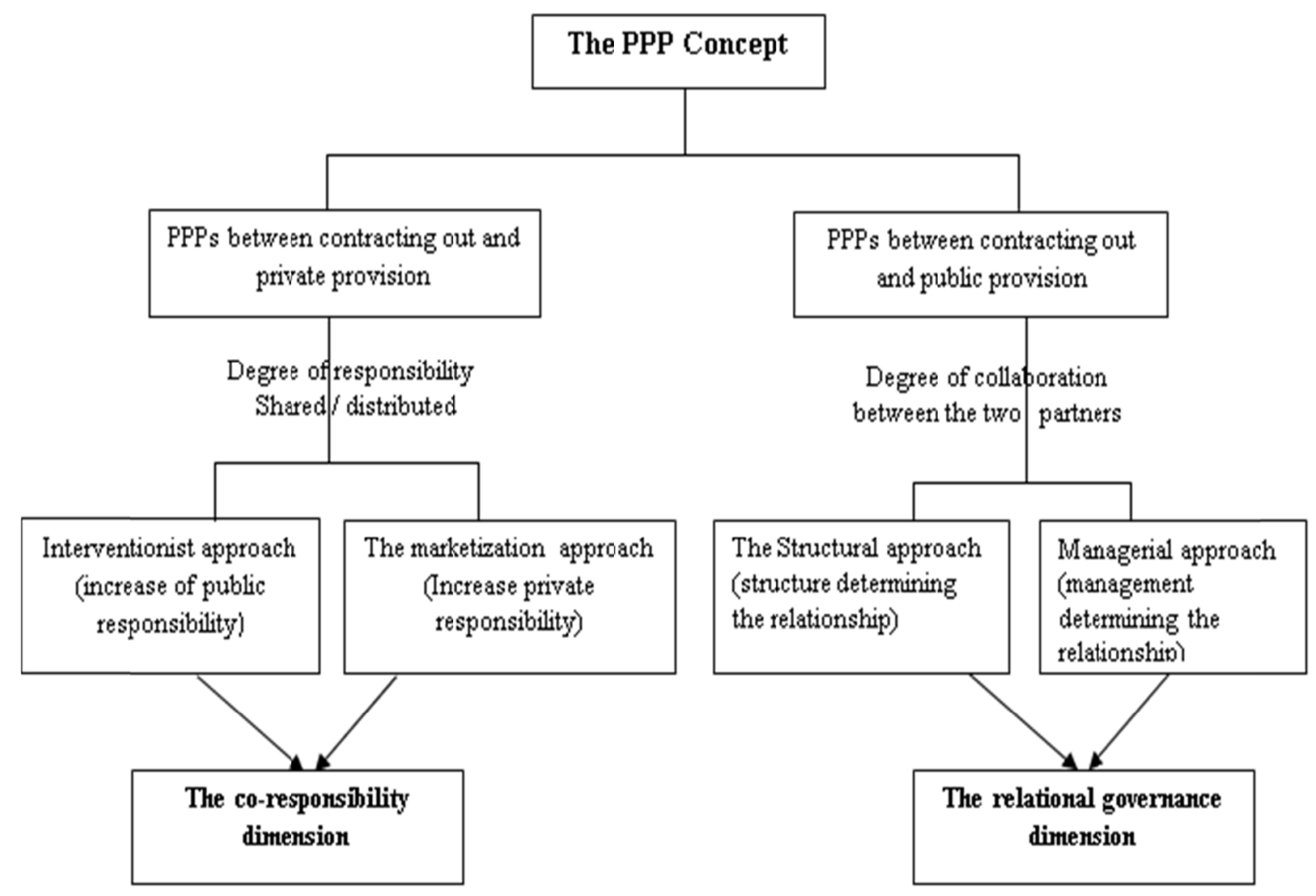

Figure 1. Public private partnership approaches

Source: Modified from Stelling (2014)

Based on the marketization approach, the new public management theory is a reaction to the failure of the state in the provision of public services by involving the private sector with wide range of responsibilities to create more efficient delivery solutions. In fact, PPPs that employ this approach promote "the less government but more market philosophy". Therefore, the responsibilities and powers of government are minimised to a level of just making policies and overseeing the achievement of set performance targets by the private sector. Unfortunately, with such PPP delivery approach, there is a tendency of the private sector to be preoccupied with maximising profits rather than delivering effective public services.

Based on the interventionist approach, the NPS and PV theories are a response to the deficiencies of the private organisations in the delivery of public services. The bureaucrats and citizens are given more powers to guide the provision of public services in order to protect the overall society interests against cruel behaviour of some private sector players. Though the private sector still has greater responsibilities in the execution of actual PPP project tasks, its powers to direct the provision of public services are minimised, and its performance is heavily regulated and closely monitored by public sector managers in collaboration with the citizens. The New public service and Public value principles can do well in countries with some credible level of democracy or on government projects where intergovernmental organisations that promote good governance are involved. Compared to the New Public Service theory, what makes the public value theory stand out is the fact that scholars have provided frameworks that can be used to legitimize, create and measure the provision of public valued services.

Based on the structural and managerial approaches, the New Public Governance theory is a response to both the market and government failures in the provision of public services. The New public governance emphases joint value creation through inclusive public service delivery collaborative relationships. The powers of the public managers, private sector players and the elected political representatives are minimised since public service delivery decisions are made and implemented based on joint and semi-joint institutional, formal and informal organisational, contractual and non-contractual structures through mutual managerial strategies and interactions. As a consequence, neither the public nor the private sector players can directly force other project actors to behave in ways that are against their will. 
From the deductions above, it can be concluded that the main contribution of NPS and PV over NPM is the view that public sector powers in the provision of public services need to be strengthened rather than minimized. On the other hand, unlike NPG that is all-embracive, NPM, NPS and PV focus on PPP projects delivering efficient and effective public services, but are less interested in inter-organisational collaborations. In fact, the NPM, NPS and PV subscribe to the partner co-responsibility dimensions where the focus is on sharing or distribution of responsibilities, while, NPG subscribes to the Partnership relational governance dimensions where the interest is on joint value creation and mutual decision-making. However, according to Stelling (2014, p.13), though 'co-responsibility and relational governance are separate dimensions, PPPs require both a partnership as well as autonomous and responsible partners since there is no partnership without partners and no partners without a partnership'.

\section{Conclusion}

Essentially, PPPs is a new service delivery instrument that complements conventional public service delivery methods especially in instances where direct government provisioning or outsourcing (public procurement) would be less effective. However, like any other public service delivery approach, PPPs have a multitude of challenges. As such, their positive contribution can only be realised if challenges from macro, meso and micro environments are supressed.

Findings from the conceptual investigation indicated that PPPs cannot have a single meaning and application style (Hodge et al., 2018) because of the various research traditions and professions with different knowledge clusters and usage that have gained interest in the concept itself. Misconceptualization and misunderstanding of what PPPs are and what they are not has been magnified by failure to acknowledge the existence of different PPP perspectives as well as their uniqueness in usage or application. In order to provide a more concrete understanding of PPPs, key common features that define PPPs and eight PPP perspectives were highlighted and discussed. Importantly, this paper introduces a new and overarching PPP perspective of procurement management. For instance, while a number of scholars have viewed private financing as an independent PPP perspective, this study concurs with Hodge et al. (2018, p.1115-1116) who state that, 'private financing is one component of a suite of modern procurement strategies'. This implies that financing is part of the procurement management perspective for PPP project arrangements.

Finally, findings from the theoretical investigation suggested that PPPs are not suitable under traditional public administration practices; instead they (PPPs) work well in environments that promote co-regulation, co-production, co-responsibility and relational governance. Therefore, the need for governments to change from the traditional way of doing things when undertaking PPP projects to more innovative public service delivery practices underpinned by new public governance, public value, and new public service, and to a lesser extent new public management.

\section{References}

Airoldi, M., Chua, J., Gerbert, P. Justus, J., \& Rilo, R. (2013). Meeting the Infrastructure Challenge with Public-Private Partnerships. Retrieved from https://www.bcgperspectives.com/content/articles/public_sector_transportation_travel_tourism_meeting_th e_infrastructure_challenge_with_public_private_partnerships/

Alford, J., \& Hughes, O. (2008). Public value pragmatism as the next phase of public management. American Review of Public Administration, 38(2), 130-148. https://doi.org/10.1177/0275074008314203

Alinaitwe, H., \& Ayesiga, R. (2013). Success factors for the implementation of Public-Private Partnerships in the Construction Industry in Uganda. Journal of Construction in Developing Countries, 18(2), 1-14.

Allen Consulting Group. (2007). Performance of PPPs and Traditional Procurement in Australia. Report to Infrastructure Partnerships Australia. Melbourne: Allen Consulting Group.

Bao, G., Wang, X., Larsen, G. L., \& Morgan, D. F. (2012). Beyond New Public Governance: A Value-Based Global Framework for Performance Management, Governance, and Leadership. Administration \& Society, 45(4), 443-467. https://doi.org/10.1177/0095399712464952

Bayliss, K., \& Van Waeyenberge, E. (2018). Unpacking the public private partnership revival. The Journal of Development Studies, 54(4), 577-593. https://doi.org/10.1080/00220388.2017.1303671

Benington, J. (2007). From Private Choice to Public Value? Institute of Governance and Public Management (IGPM). Warwick Business School, The University of Warwick, UK.

Blaug, R., Horner, L., \& Lekhi, R. (2006). Public value, politics and public Management. A literature review. 
The Work Foundation, 3 Carlton House Terrace, London.

Boardman, A. E., Greve, C., \& Hodge, G. A. (2015). Comparative Analyses of Infrastructure Public-Private Partnerships. Journal of Comparative Policy Analysis: Research and Practice, 17(5), 441-447. https://doi.org/10.1080/13876988.2015.1052611

Bonina, C. M., \& Cordella, A. (2009). Public sector reforms and the notion of 'public value': implications for e-government deployment. In: 15th Americas Conference on Information Systems, 6th-9th August, San Francisco, California. (Unpublished).

Bovaird, T. (2004). Public-private partnerships: from contested concepts to prevalent practice. International Review of Administrative Sciences, 70(2), 199-215. https://doi.org/10.1177/0020852304044250

Bozeman, B. (2007). Public values and public interest: Counterbalancing economic individualism. Washington, DC: Georgetown University Press.

Brinkerhoff, D. W., \& Brinkerhoff, J. M. (2011). Public-Private Partnerships: Perspectives on Purposes, Publicness, and Good Governance. Public Administration and Development, 31, 2-14. https://doi.org/10.1002/pad.584

Byamugisha, A., \& Basheka, C. (2016). Measuring the performance of the economic infrastructure and competitiveness cluster in Uganda. Journal of Public Administration and Policy Research, 8(1), 1-11. https://doi.org/10.5897/JPAPR2015.0319

Campbell, G. (2001). Public- Private Partnerships- A Developing Market?. Melbourne, Unpublished.

Casady, C. (2016). PPP Procurement in Canada: An Analysis of Tendering Periods. Department of Policy Analysis \& Management, College of Human Ecology, Cornell University: Ithaca, New York, U.S.A.

Coats, D. (2006). Reviving the Public: A New Governance and Management Model for Public Services. The Work Foundation, Peter Runge House, 3 Carlton House Terrace, London.

Coyle, D., \& Woolard, C. (2010). Public Value in Practice-restoring the ethos of public service. Getting the best out of the BBC for license fee payers.

Denhardt, R. B., \& Denhardt, J. V. (2000). The New Public Service, Serving Rather than Steering. Public Administration Review, 60(6), 549-59. https://doi.org/10.1111/0033-3352.00117

Denhardt, R. B., \& Denhardt, J. V. (2007). The New Public Service: Serving, Not Steering. Expanded ed: M.E. Sharpe, Inc., 80 Business Park Drive, Armonk, New York 10504.

Denhardt, R. B., \& Denhardt, J. V. (2015). The New Public Service Revisited. The American Society for Public Administration. Public Administration Review, 75(5), 664-672. https://doi.org/10.1111/puar.12347

Farquharson, E., Torres de Mästle, C., \& Yescombe, E.R. (2011). How to engage with the private sector in public-private partnerships in emerging markets. The World Bank. https://doi.org/10.1596/978-0-8213-7863-2

Ghobadian, A., Gallear, D., O'Reagan, N., \& Viney, H. (2004). Public-Private Partnerships. Policy and Experience. Basingstoke: Palgrave Macmillean.

Greve, C. (2003). Public-Private Partnerships in Scandinavia. International Public Management Review, 4(2), 59-69.

Greve, C., \& Hodge, G. (2013). Rethinking Public-Private partnerships. Strategies for turbulent times. Routledge critical studies in Public Management. https://doi.org/10.4324/9780203108130

Grimsey, D., \& Lewis, M. (2004). Public Private Partnerships. The Worldwide Revolution in Infrastructure Provision and Project Finance. Cheltenham \& Northampton. Edward Elgar Publishing Limited \& Edward Elgar Publishing, Inc. https://doi.org/10.4337/9781845423438

Hodge, G. (2009). Delivering Performance Improvements through Public Private Partnerships: Defining and Evaluating a Phenomenon. International Conference on Administrative Development: Towards Excellence in Public Sector Performance. Riyadh, Kingdom of Saudi Arabia, November 1-4, 2009.

Hodge, G. A. (2004). The risky business of public-private partnerships. Australian Journal of Public Administration, 63(4), 37-49. https://doi.org/10.1111/j.1467-8500.2004.00400.x

Hodge, G. A., \& Greve, C. (2007). Public-Private Partnerships: An International Performance Review. Essays on Service Delivery and Privatization. Public Administration Review. 
https://doi.org/10.1111/j.1540-6210.2007.00736.x

Hodge, G. A., \& Greve, C. (2009). PPPs: The Passage of Time Permits a Sober Reflection. Institute of Economic Affairs 2009. Published by Blackwell Publishing, Oxford. https://doi.org/10.1111/j.1468-0270.2009.01864.x

Hodge, G., \& Greve, C. (2005a). PPPs: An International Performance Review. Paper presented at the American Midwest Political Science Association Conference, 8-11 April 2005.

Hodge, G., \& Greve, C. (2005b). The Challenge of Public Private Partnerships. Edward Elgar, UK \& USA. https://doi.org/10.4337/9781845428082

Hodge, G., \& Greve, C. (2010). Public-private partnerships: governance scheme or language game? Australian Journal of Public Administration, 69(1), S8-S22. https://doi.org/10.1111/j.1467-8500.2009.00659.x

Hodge, G., Greve, C., \& Biygautane, M., (2018). Do PPP's work? What and how have we been learning so far? Public Management Review, 20(8), 1105-1121. https://doi.org/10.1080/14719037.2018.1428410

Kalpana, G. (2014a). Public Private Partnerships. A study in Organizational Design. https://doi.org/10.2139/ssrn.2382648

Kalpana, G. (2014b). Public Private Partnerships. A Comprehensive Survey of Literature.

Kennett, P. (2010). Global Perspective on Governance. In: The New Public Governance? Emerging perspectives on the theory and practice of public governance. Edited by Stephen p. Osborne. Routledge, New York and London.

Khanom, N. A. (2009). Conceptual Issues in Defining Public Private Partnerships (PPPs). Paper for Asian Business Research Conference 2009. University of Canberra, ACT- 2601 Australia.

Klijn, E.H. (2010). Public Private Partnerships: Deciphering meaning, message and phenomenon. In Hodge, G., \& Greve, C. (Eds.), International Handbook of PPP (pp. 68-80). Cheltenham: Edgar.

Koenig-Archibugi, M. (2003). Global Governance. In J. Mitchie (Ed.), The Handbook of Globalisation. Cheltenham: Edward Elgar.

Kooiman, J. (1993). Social-Political Governance. In J. Kooiman (Ed.), Modern Governance. London: Sage.

Koppenjan, J. F. M. (2005). The formation of public-private partnerships: lessons from nine transport infrastructure projects in The Netherlands. Public Administration, 83(1), 135-157. https://doi.org/10.1111/j.0033-3298.2005.00441.x

Li, S. (2017). Modeling, Optimizing, and Impact Analysis of Incentive and Regulation Mechanisms in Infrastructure Privatization (Doctoral dissertation, Purdue University).

Linder, S. H. (1999). Coming to terms with the Public Private Partnership: A grammar of multiple meanings. The American Behavioural Scientist, 43(1), 35-51. https://doi.org/10.1177/00027649921955146

Martin, L., Lawther, W., Hodge, G., \& Greve, C. (2013). Internationally recommended best practices in transportation financing public-private partnerships (P3s). Public Administration Research, 2(2), 15-25. https://doi.org/10.5539/par.v2n2p15

Mauri, A. G., \& Muccio, S. (2012). The Public Management Reform: from Theory to Practice. The Role of Cultural Factors. International Journal of Advances in Management Science, 1(3), 47-56.

Meynhardt, T. (2012). Public Value-Turning a Conceptual Framework into a Scorecard. Creating Public Value in a Multi-Sector, Shared-Power World. Draft paper prepared for Creating Public Value Conference, University of Minnesota, Sept 20-22, 2012.

Mingus, M., \& Zhu, J. (2018). Increasing Citizen Access and Local Government Responsiveness in Yichang, China. International Public Management Journal, 21(3), 369-391. https://doi.org/10.1080/10967494.2017.1399945

Mongkol, K. (2011). The Critical Review of the New Public Management Model and its Criticisms. Research Journal of Business Management, 5(1), 35-43. https://doi.org/10.3923/rjbm.2011.35.43

Ong'olo, D. (2006). Public Private Partnerships (PPP) Practice and Regulatory Policy in Kenya. Paper prepared for The Institute of Economic Affairs (IEA, Kenya). Spellman \& Walker Co. Ltd.

Osborne, S. P. (2010). The New Public Governance? Emerging perspectives on the theory and practice of public governance. Routledge, New York and London. https://doi.org/10.4324/9780203861684 
Patapas, A., Raipa, A., \& Smalskys, V. (2014). New Public Governance: The Tracks of Changes. International Journal of Business and Social Research (IJBSR), 4(5).

Peters, B. G. (2010). Meta-Governmence and Public Management. In S. P. Osborne (Ed.), The New Public Governance? Emerging perspectives on the theory and practice of public governance. Routledge, New York and London.

Reim, C. (2009). Challenges to Public Private Partnerships. The Example of the London Underground PPPs (Doctoral dissertation, University of Potsdam).

Rhodes, R. A. W. (1996). The new governance: Governing without government. Political Studies, 652-667. https://doi.org/10.1111/j.1467-9248.1996.tb01747.x

Rhodes, R. A. W. (2016). The Theory and Practice of Governance. The next steps.

Roberts, D. J., \& Siemiatycki, M. (2015). Fostering meaningful partnerships in public-private partnerships: innovations in partnership design and process management to create value. Environment and Planning C: Government and Policy, 33, 780-793. https://doi.org/10.1068/c12250

Robinson, M. (2015). From Old Public Administration to the New Public Service Implications for Public Sector Reform in Developing Countries. UNDP Global Centre for Public Service Excellence, 29 Heng Mui Keng Terrace, 119620 Singapore.

Rutgers, M. R. (2015). As Good as It Gets? On the Meaning of Public Value in the Study of Policy and Management. American Review of Public Administration, 45(1), 29-45. https://doi.org/10.1177/0275074014525833

Sarmento, J. M., \& Renneboog, L. (2016). Anatomy of public-private partnerships: their creation, financing and renegotiations. International Journal of Managing Projects in Business, 9(1), 94-122. https://doi.org/10.1108/JJMPB-03-2015-0023

Shetterly, R. D., Duan, C. J., Krishnamoorthy, A., Kronenburg, M., \& Loutzenhiser, K. (2012). The impact of contract design on contractor performance-a second look. In Conference Proceedings, at the International Public Procurement Conference Paper, 5, 996-1000.

Spano, A. (2009). Public Value Creation and Management Control Systems. International Journal of Public Administration, 32(3), 328-348. https://doi.org/10.1080/01900690902732848

Stelling, C. (2014). An Excursion Into The Public-Private Partnership Jungle: Stop Standardizing But Keep On Mapping! International Public Management Review, 15(1), 1-28.

Sufna, M. N. N., \& Fernand, R. L. S. (2015). Factors affecting Public Value of E-government in Sri Lanka: An Empirical Study based on the Ministry of Public Administration and Home Affairs. Proceedings of 12th International Conference on Business Management: 7th and 8th December, Colombo, Sri Lanka. Retrieved from http://ssrn.com/link/12th-ICBM-2015.html

Supiot, A. (1996). Work and public/Private dichotomy. International Labour Review, 135, 653-663.

Talbot, C. (2008). Measuring Public Value. A competing values approach. A paper for The Work Foundation. 21 Palmer Street, London, SW1H 0AD.

The Global Fund. (2016). The Global Fund Overview. Retrieved September 15, 2016, from www.theglobalfund.org/

Villanueva, L. F. A. (2015). Reviews, 1(1). In S. P. Osborne (Ed.), The New Public Governance? Emerging perspectives on the theory and practice of public governance. Routledge, New York and London.

Weihe, G. (2008). Research and Evaluation. Ordering Disorder-On the Perplexities of the Partnership Literature. The Australian Journal of Public Administration, 67(4), 430-442. https://doi.org/10.1111/j.1467-8500.2008.00600.x

Wettenhall, R. (2003). The Rhetoric and Reality of Public-Private Partnerships. Public Organization Review: A Global Journal, 3(1), 77-107. https://doi.org/10.1023/A:1023000128175

Willems, T., \& Van Dooren, W. (2016). (De) Politicization Dynamics in Public-Private Partnerships (PPPs): Lessons from a comparison between UK and Flemish PPP policy. Public Management Review, 18(2), 199-220. https://doi.org/10.1080/14719037.2014.969759

Willems, T., Van Dooren, W., \& van den Hurk, M. (2017). PPP policy, depoliticisation, and anti-politics. Partecipazione e conflitto, 10(2), 448-471. 
Xu, R. Y., Sun, Q. G., \& Si, W. (2015). The Third Wave of Public Administration: The New Public Governance. Canadian Social Science, 11(7), 11-21.

Zhang, S., Gao, Y., Feng, Z., \& Sun, W. (2015). PPP application in infrastructure development in China: Institutional analysis and implications. International Journal of Project Management, 33, 497-509. https://doi.org/10.1016/j.ijproman.2014.06.006

\section{Copyrights}

Copyright for this article is retained by the author(s), with first publication rights granted to the journal.

This is an open-access article distributed under the terms and conditions of the Creative Commons Attribution license (http://creativecommons.org/licenses/by/4.0/). 